


\title{
UCLA FORUM IN MEDICAL SCIENCES
}

\author{
Victor E. HaLl, Editor
}

Martha Bascopí-Vargas, Assistant Editor

\section{EDITORIAL BOARD}

\author{
Forrest H. Adams \\ H. W. Magoun \\ Mary A. B. Brazier \\ C. D. O’Malley \\ Louise L. Darling \\ Morton L. Pearce \\ Morton I. Grossman \\ Sidney Roberts \\ William P. Longmire \\ Emil L. Smith \\ Reidar F. Sognnaes
}


GASTRIN 



\title{
UCLA FORUM IN MEDICAL SCIENCES NUMBER 5
}

\section{GASTRIN}

Proceedings of a Conference held in September, 1964

Sponsored by the School of Medicine, University of California, Los Angeles

\author{
EDITOR
}

MORTON I. GROSSMAN

UNIVERSITY OF CALIFORNIA PRESS

BERKELEY AND LOS ANGELES 


\section{CITATION FORM}

Grossman, M. I. (Ed.), Gastrin. UCLA Forum Med. Sci. No. 5, University of California Press, Los Angeles, 1966.

University of California Press

Berkeley and Los Angeles, California

(C) 1966 by The Regents of the University of California

Library of Congress Catalog Card Number: 66-25614

Printed in the United States of America 


\title{
PARTICIPANTS IN THE CONFERENCE
}

\author{
Morton I. Grossman, Chairman and Editor \\ Division of Gastroenterology, Veterans Administration Center \\ Los Angeles, California
}

\author{
SVEn ANdersson \\ Department of Pharmacology, Karolinska Institutet \\ Stockholm, Sweden
}

E. L. BLAIR

Department of Physiology

The Medical School, The University of Newcastle upon Tyne

Newcastle upon Tyne, England

\author{
W. I. CARD \\ Gastro-Intestinal Unit, Western General Hospital \\ and University of Edinburgh \\ Edinburgh, Scotland \\ Charres F. Code \\ Section of Physiology, Mayo Foundation \\ Rochester, Minnesota \\ Lester Dragstedt \\ Department of Surgery, University of Florida \\ Gainesville, Florida \\ IAin E. GiLlespie \\ Department of Surgery, Western Infirmary \\ University of Glasgow \\ Glasgow, Scotland \\ R. A. GREGory \\ The Physiological Laboratory, The University of Liverpool \\ Liverpool, England \\ George A. HaLlenbeck \\ Section of Surgical Research, Mayo Clinic and Mayo Foundation \\ Rochester, Minnesota \\ Bernard J. Haverback \\ Department of Medicine, University of Southern California \\ Los Angeles, California
}




\section{Gabriel M. Makhlouf \\ Gastro-Intestinal Unit, Western General Hospital \\ Edinburgh, Scotland

\author{
LaRs Olbe* \\ Department of Pharmacology, Karolinska Institutet \\ Stockholm, Sweden
}

Roy M. Preshawł

Gastrointestinal Research Laboratory, Veterans Administration Center

Los Angeles, California

Brian Schofield

Department of Physiology

The Medical School, The University of Newcastle upon Tyne

Newcastle upon Tyne, England

EML L. SMrTH

Department of Biological Chemistry, University of California, Los Angeles

Los Angeles, California

STUART D. TAuber

Department of Internal Medicine

Southwestern Medical School, The University of Texas

Dallas, Texas

JAMes C. Thompson

Department of Surgery, University of California, Los Angeles

Los Angeles, California

BöRJE UVNÄS

Department of Pharmacology, Karolinska Institutet

Stockholm, Sweden

\footnotetext{
- Present Address: Surgical Clinic II, Sahlgrenska Hospital

Göteborg, Sweden

+ Present Address: Department of Experimental Surgery, McGill University Montreal, Canada
} 


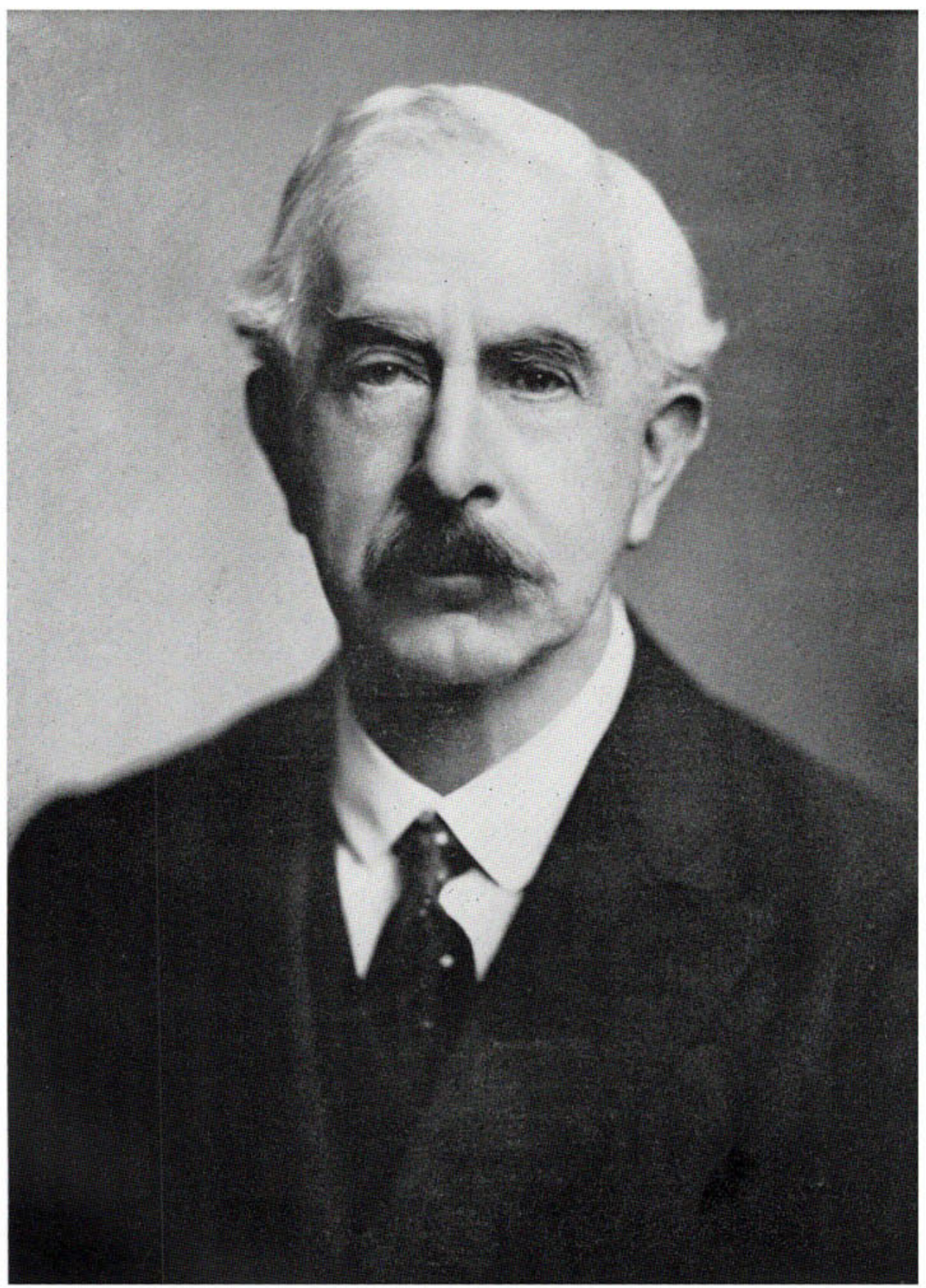

JOHN SYDNEY EDKINS

1863-1940

The Discoverer of Gastrin 
